\title{
Několik postřehů ze XVI. mezinárodního kongresu slavistů v Bělehradě ${ }^{1}$
}

\author{
Alexej Mikulášek (Praha) - Giuseppe Maiello (Praha) - Lenka Paučová (Brno)
}

Šlo o reprezentativní vědecký kongres navštívený stovkami badatelů-slavistů snad ze všech zemí planety, v nichž existují slavistická studia, katedry a ústavy... Jeho průběh, výjimečné referáty, metodologické a metodické trendy a směry, opatrné závěry a výhledy do budoucna, to vše bude v souvislosti s kongresem, konaným ve dnech 20.-27. 8. 2018, ještě dlouho a dlouho diskutováno. ${ }^{2}$ Byl nesporně velmi podnětný, jakkoliv se objevily i některé výhrady a pochyby.

Jednání v sekcích, v rámci plenárních zasedání tzv. tematických bloků, ale i tzv. kulaté stoly nepřímo nastolily řadu otázek. Které pokládáme za zásadní? Ta první se soustředuje kolem pojmů „postkoloniální literatura“ nebo „postkoloniální román“, které vyvolávají asociace spíše politické než literární, spíše „geo-politické“ než "geo-poetické“ povahy. Fakt omezené suverenity zemí podřízených Sovětskému svazu přímo nezakládá uniformitu témat ani stylů, podobně jako začlenění českých a moravských zemí do rakouské, resp. rakousko-uherské monarchie nezakládá existenci „rakouské“, „habsburské“, „koloniální “ české či moravské literatury. Alespoň si nedovedu představit výklady Boženy Němcové,

1 Redakční poznámka: Redakce časopisu Slavica litteraria se touto zprávou s jistým odstupem vrací k XVI. mezinárodnímu kongresu slavistů v Bělehradě v srpnu 2018. Nejde o komplexní zhodnocení sjezdového jednání, ale o několik postřehů osobních účastníků s přípustnou mírou subjektivních pohledů, které vytvářejí s různou mírou interpretačního ponoru dílčí, nicméně detailní „střípky“, postihující referáty, metodické trendy a diskuse na kongresu.

2 Př́spěvky členů (účastníků i těch, kteří se kongresu osobně neúčastnili) České asociace slavistů byly publikovány v kolektivní monografii Česká slavistika 2018. Eds. Ivo Pospíšil - Miloš Zelenka - Lenka Paučová. Brno: Jan Sojnek - Galium, 2018. Autoři studií: I. Pospíšil, J. Gazda, A. Jensterle-Doležalová, J. Kesner, S. Koryčánková, J. Kostincová, P. Kučera, G. Maiello, E. Kudrjavceva Malenová, A. Mikulášek, L. Paučová, L. Pavera, M. Pokorný, J. Šaur, M. Zelenka, A. Zelenková.
Karla Havlíčka Borovského, Jana Nerudy či jakéhokoli směru či literární skupiny v rámci literárně relevantního celku zvaného „habsburská literatura“. Ani meziválečnou českou či slovenskou literaturu nevidím jako „posthabsburskou“ literaturu jakési postmonarchie, český či slovenský román dvacátých a třicátých let minulého stoletî jako „posthabsburský“. Nesporně však existoval relevantní životní pocit nesvobody, života „sub tegmine fagi“ jako života „pod jařmem“, odpor k rakouským a německým autoritám projevovaný v literární tvorbě, která nezrrídka „suplovala“ liberální politický systém (současně se však stávala významnou složkou „měkké síly“). Existoval i pocit „koloniální závislosti“ a rozdělení horizontu na „my a oni“, stejně jako pocit vítězství, když ,jsme bourali vesele Rakousko zpuchřelé“, abych parafrázoval jednoho českého klasika.

Země bývalého socialistického bloku neměly přímý status kolonií, byly formálně samostatné, byly subjekty mezinárodního práva a OSN, měly jistou autonomii v rámci RVHP. I cenzuru bylo možné obejít tím, že se „počkalo na lepší časy“, a tak se mnozí spisovatelé „vraceli do literatury“, hledaly se nejrůznější kompromisy, pokud to bylo nutné (nejčastěji), nebo se publikovalo v zahraničí (blízkém i vzdáleném, více liberálním Polsku, Mad’arsku), popř. v samizdatu. Jen velmi volně a metaforicky lze označit literaturu tzv. normalizace za „koloniální“ a slovesnou produkci po pádu socialistického bloku za "postkoloniální", při vědomí radikálních změn hodnotového i jiného systému. Daleko zdůvodněnější se mi však jeví výzkum takových jevů, jako je např. (slovanský) modernismus a postmodernismus ve smyslu modernismu a postmodernismu v jednotlivých slovanských literaturách, nebo hledání kontinuitně-diskontinuitních jevů v literatuře osmdesátých a časově (i jinak) navazujících devadesátých let etc. 
Literární sekce byly tematicky heterogenní a některé $\mathrm{z}$ nich rovněž negativně poznamenány neúčastí referujících. V sekci, v níž jsme měli možnost prezentovat některé závěry našeho studia, byli z pěti referujících přítomni pouze tři a ochota diskutovat velmi, velmi malá, což bylo snad dáno citlivostí problematiky a nebezpečím její „politizace“; snaha o depolitizaci byla výraznou tendencí kongresu a v tomto smyslu i úspěšnou; k ní přistupuje i úsilí o vytváření pluralitní a tolerantní atmosféry - obě tendence se jeví jako podstatně silnější než snahy jim protikladné. Jinde byl počet účastníků dokonce nižší. Na druhou stranu existovaly sekce obsazené tak, že nebylo možné najít volnou židli a jednání trvala dlouho po oficiálně plánovaném konci.

Jako negativní se nám jeví přetrvávající vědomí slovanských literatur jako mechanického součtu literatur a kultur užívajících slovanský jazyk. Základem jsou vlastně „literatury slovanských zemí“ nebo „psané slovanskými jazyky“. Přínosnější se nám jeví chápání slovanských literatur jako sítě meziliterárních vztahů, přičemž se však poněkud mechanicky studují jen paralely, vztahy a podněty genetické i jiné povahy, recepce toho či onoho autora (autorů) v jiné slovanské literatuře (překlady, kritiky, počty výpůjček etc.). Postrádali jsme výzkum slavismu jako konkrétní historické formy sebe-uvědomění a sebe-uvědomování si toho či onoho literárně příznakového jevu - právě jako slovanského (popř. dokonce „protislovanského“ nebo „semislovanského“ atd.) V aplikaci na materiál český: slavismus reformační, humanistický, barokní, obrozenecký (včetně podob slavjanofilství), slavismus rakouský (austroslavismus), československý etc., až po takové jevy, jakými je studium slovanských literatur jako integrální součásti literatury evropské, popř. tzv. euroslavismus (s „unijním“ podtextem), či židovská slavistická studia (vidění židovského prvku jako součásti slavistické problematiky), to vše představuje další výzvy, jak se dnes poněkud módně píše.

Nejednou bylo zvláště srbskými nebo makedonskými kolegy definováno, jaké stereotypní představy existují např. o Jugoslávii nebo Balkánu vůbec. Platí to jistě i v „opačném gardu“.
Lze rovněž připomenout, a rovněž „nihil novi sub sole“, jak je stigmatizováno slavistické studium neoddělované od různých podob slavjanofilství nebo „všeslovanství“, jakkoli i tyto jsou předmětem studia. To je sice dnes akademicky akceptovaný fakt, ovšem např. v literární výuce, v běžném „občanském“ povědomí, v tak či onak povrchních žurnalistických úvahách, popř. v dalších formách veřejného diskurzu jsme však svědky čehosi zcela opačného.

Slavisticky prríznakové a relevantní jevy nelze $\mathrm{v}$ areálovém studiu oddělit od těch neslovanských, nebot jevy tzv. výlučně germanistického zájmu mají výraznou „slovanskou vrstvu“, jako je tomu u R. M. Rilka (zvláště v prvním období tvorby, „slovanském“), nebo F. Kafky v celku „pražské německé literatury“, a to nehledě na francouzsky psané verše Rilkovy a na sebe-uvědomované židovství Franze Kafky; toto před-nastavuje vědeckou i čtenářskou recepci jeho děl jako obrazu židovského údělu, osamocenosti, odcizení, hledání Boha a domoviny etc. Jakkoli se podobná recepce může jevit problematická, v individuální i kolektivní literární recepci platí, že „být znamená být vnímán“.

Zkoumání těchto slovansko-neslovanských vztahů je mimořádně důležité nejen pro „poetiku slovanského areálu“, ale rovněž pro pochopení mezních, hraničních, na styku různých proudů a kultur existujících osobností, děl, žánrů a témat, motivů a „ideologémat“. Např. fakt, že je Franz Kafka někdy chápán (našimi i cizími čtenáři, studenty, učiteli etc.) jako český spisovatel sui generis, zakládá velmi paradoxní situaci: např. tento před-nastavený rámec vnímání konceptualizuje zobrazené prostředí právě jako „česko-slovanské“, při vší problematičnosti této recepce. Odtud např. jednoznačná situovanost povídky/novely Proměna/Verwandlung do českojazyčné Prahy ve filmové podobě (tedy interpretaci) režiséra V. Fokina Prevraščenije, která je jistě umělecky působivá a přesvědčivá.

Nemůže být cílem tohoto textu sumarizovat přednesené referáty ani komentovat vybrané, už vzhledem k připomínané heterogenitě přednášených textů a témat. Snad jen na okraj připomeneme několik myšlenek, které byly v něčem až 
provokativní. Srov. „Тематски блок 3.1“ nazvanу́ Представления о регионах Европы в истории славистики“, jehož organizátor Leonid Gorizontov v př́íspěvku Региональная терминология в российской славистике последнего столетия upozornil na řadu problémů plynoucích z užití pojmu „centrálně-východni" Evropa a vůbec vydělování Ruska z Evropy, přičemž střední Evropa mu vystupuje spíše jako zeměpisná, nikoli kulturní entita. Pojem „centrálně-východni" Evropa byl vytvořen emigranty, kteří se stávali vlivnými profesory amerických univerzit. L'ubor Matejko v ruskojazyčném př́spěvku sledoval „mentálne hranice v Európe“ a s nimi spjatý „literárny diskurz", přičemž sledoval překladovou produkci do slovenštiny, existenci dvou mýtů (o Západě i o Východě), a následně průběh „demytizace“. Miloš Zelenka v tomtéž bloku v prríspěvku Центральная Европа в представлении чешских славистов межвоенного периода připomenul maximalistické i minimalistické hledisko při „ohraničení“ tohoto pojmu, pohledy R. Wellekovy a R. Jakobsonovy, jeho koncepci „mostu“ mezi Západem a Východem, soudy D. Čyževského, F. Wollmana i J. Křena (pojem „habsburský člověk“ vyvolal živou diskusi). I další referáty tohoto bloku byly podnětné, jako např. Michaila Robinsona Регионы Европь в историософском трактате В. И. Ламанского „Три мира Азийско-Европейского материка", Rafała Stobieckého Europa Środkowo-Wschodnia w polskim dyskursie publicznym. Wczoraj $i$ dziś i Helmuta Schallera Serbian language and literature in Germany in the XXth century: Gerhard Gesemann and Alois Schmaus.

Diskusi o pojmu „cenzura“ vzbudil příspěvek v úterní tematické sekci 2.7.1 (Публицистика, медији, критика). Vyprovokoval ji Alexej Svetlanovič Semenenko svým referátem na téma Сатира и иензура в современной России. Výhrady se týkaly malého počtu vybraných a sledovaných televizních programů (tj. pouze dvou) a neoddělování redakčního výběru od cenzury jako instituce. Dodejme, že je sice sporné, zda cenzura musí mít institucionální, administrativně úř̌ední bázi, avšak metody „cenzury“ ve sledovaných televizích (zde napřr. „vystřižení“ žertů na adresu ruských autorit, Medveděva a Putina), resp. záměrné nevysílání toho, co není v souladu s ideově programovým záměrem redakce a vlivných politických autorit, je běžnou součástí praktik českého veřejného prostoru, jmenovitě České televize a jejího zpravodajství.

V úterní sekci 2.6 (Превод) se prezentovaly dva doplňující se referáty věnované „multilingvismu“ v díle V. Nabokova. Pieter Boulogne z Belgie přednesl referát Translation as reality, fiction and metafiction in Nabokov's first American novel Bend Sinister and in its Russian translation Под знаком незаконнорождённых, mad’arská účastnice Zsuzsa Hetényi pak výklad na podobné téma pod názvem Translating self-translation and the units of translation (Philology in translating $\mathrm{V}$. Nabokov). Ukazuje se, jakou „soukromou tragédii“ se stává skutečnost, že spisovatel je nucen „opustit svůj přirozený narativ, bohatý a nekonečný ruský jazyk“, což na druhé straně provokuje kreativitu, citlivost k jazykové polysémii a parodičnosti, vznik metafikce a metafikční ironie (kombinující různé jazyky, zvláště angličtinu s ruštinou). Bylo rovněž konstatováno, že žádný čtenář nikdy plně neporozumí literárnímu dílu, at již jednojazyčnému, nebo mnohojazyčnému.

Širokou odezvu vzbudil ve středeční sekci 2.9.1 (Словенске књижевности и културно наслеђе у XXI веку) Venko Andonovski referátem nazvaným poněkud postmoderně Dostojevskij i Macdonalds, v němž pracoval s pojmem „globalizovaná literatura“, „ready made“ a „fast food“ literatura, o níž soudí, že je kýčovitá a klišovitá. Literatura je tu zaměněna za tvưrčí psaní a její texty jsou zaměřeny na prvoplánový úspěch u čtenářù; jsou silně stereotypní, což autor referátu ukazoval na jejich strategii stigmatizovat muslimy a Slovany (z nich zvláště Rusy a Srby). Přisuzuje jí melodramatický genom, fatalismus, nutkavou potřebu vyvolávat pocit strachu, také jazykovou i myšlenkovou tautologičnost a přítomnost četných pleonasmů. Podle kritiků referátu však V. Andonovski přeceňuje rozdíl mezi „originalitou“ a „panelovitostí“; vše jednou musí být první, poté se však opakuje a opakuje... Podle našeho názoru je problém recepce „ready made“ literatury v něčem jiném, protože 
se do ní automaticky zahrnuje i literatura, dejme tomu, „středního proudu“, reprezentovaná dnes např. detektivní novelou a románem, některými fantasy romány, literaturou špionážní a „spekulativní“ či „konspirativní“. Jde o proud, jenž se slovesně i hodnotově odlišuje od braku typu „harlekýnek“, s nímž má některé společné rysy, ovšem oslovuje i náročnější čtenáře; samozřejmě „úroveň Dostojevského“ od těchto knih čekat nemůžeme, a ani nechceme.

Z několika desítek vyslechnutých referátů připomeňme ještě $K$ проблеме диалогичности текстов Лъва Толстого: чужой текст как свой. Izraelský badatel Vladimir Matvejevič Papernyj se ve svém vzrušeném projevu netajil svým citově hlubokým vztahem k dílu Lva N. Tolstého, z něhož zpaměti citoval. Podle badatele sice existuje názor, že „dialogičnost“ je sama o sobě estetickou hodnotou, ale Tolstoj byl „monologický“ a jeho víra též; cenil si však schopnosti lidí v dialogu najít společnou řeč a řešení. Paradoxně je proto celé jeho dílo dialogem, přestože vytváří nábožensky fundovaný a monologický „globální projekt“. Diskusi v téže sekci (2.5: Теоријски аспекти проучавања савремених словенских књижевности) pátečního zasedání vzbudil i turecký badatel Erdem Erinç referátem Литература и власть: восприятие власти в письмах Андрея Платонова. Ukazuje se, jak vzorce podřízeného vztahu ruských (a jistě nejen ruských) spisovatelů k mocenským autoritám přerůstají doby carismu a vrůstají kontinuitně do éry stalinismu.

Jediný účastník mohl být aktivním svědkem jen a pouze zlomku přednesených referátů a diskusních bloků - náš pohled je nutně velmi ohraničený. Ale i přes všechna omezení, daná snad až př́lišnou rozmanitostí jazyků přednesených referátů, heterogenitou témat referátů, nepřítomností řady referujících i organizačními změnami, je možné pohlížet na kongres jako na úspěšný. Především jako na mnohostranně podnětný, protože se někteří zúčastnění zamýšleli nad aktuálními problémy areálové slavistiky; zdůraznili mimo jiné nutnost areálového výzkumu slovansko-neslovanského a ocenili, že heterogenita přístupů nemusí být na překážku badatelským snahám komplexněji uchopit sledovaný problém, např. spoluprací jazykovědců, historiků i intermediálně zaměřených literárních badatelů.

(Alexej Mikulášek)

$\mathrm{V}$ rámci sekce Istorija i metodologija slavistike mezi dalšími významnými historiky, lingvisty a kulturology vystoupili dne 24. 8. tři čeští badatelé. Ladislav Hladký příspěvkem Česká jugoslavistika jako významná součást české slavistiky 20. století zhodnotil české práce věnované jazykům, kulturám a historii jihoslovanských národů v období 1918-1991.

Giuseppe Maiello v prŕspěvku Italská historiografie o českém národním obrození prezentoval italskou literaturu k tématu a položil si otázku, proč českému národnímu obrození vnímanému jako fenomén podobný italskému Risorgimentu nebyl ani italskými historiky a ani obecně italskými slavisty věnován patřičný zájem. Autor připomněl konstruktivistické pojetí nacionalismu, tak jak ho prezentovali Carlton Hayes a Ernest Gellner a podtrhl fakt, že i když italská historiografie vytvořila vynikající teoretické analýzy konceptu nacionalismu, z velké části opomněla studium dokumentárních pramenů období národního obrození v českých zemích.

Jako poslední z českých badatelů v této sekci vystoupil Radomír Vlček s příspěvkem Josef $M a$ curek $i$ škola istoričeskoj slavistiki v Brno. Autor připomněl úsilí významného českého historika a bývalého děkana Univerzity Jana Evangelisty Purkyně (dnešní Masarykovy univerzity) v Brně Josefa Macůrka (1901-1992), který se zasadil o to, aby se historie stala plně součástí slavistiky. Autor připomněl také působení J. Macůrka v rámci př́ípravy a realizace VI. mezinárodního sjezdu slavistů v Praze v roce 1968.

Česká asociace slavistů se stala promotérem kulatého stolu s názvem Filologičeskije arealnyje issledovanija i sovremennaja slavistika, který se konal v pátek 28. 8. v hlavní zasedací místnosti děkanátu Filologické fakulty Univerzity v Bělehradu. Hlavní řečníci byli Alexej Mikulášek a Miloš Zelenka z Česka, Petar Bunjak a Aleksandra Korda Petrović z hostující univerzity a Lucjan 
Suchanek z Polska. Emeritní profesor L. Suchanek ve svém př́spěvku v hluboce erudované formě připomněl úspěchy i neúspěchy slavistiky v posledním půl století, a zároveň se důrazně pozastavil nad současným stavem Mezinárodního komitétu slavistů, nad jeho zastaralou koncepcí a mocenskými hrami, kterým je vystaven.

$\mathrm{V}$ rámci literárněvědné, kulturologické a folkloristické části kongresu se téměř na závěr sjezdu v sobotu 25. 8. konal tematický blok s názvem Duša v slavjanskom folklore $i$ fraseologii. Z českých badatelů vystoupila Irena Vaňková s příspěvkem Přiběhy o duši v českých lidových baladách. Mezi nejzajímavější př́íspěvky patřil „Zapredać dusze diabtu“. Frazeologizmy jako reprodukty mitu, wierzeń oraz ludowego systemu wartości polské semiotičky Ewy Masłowské. Ta připomněla, že k tématu duše a jejímu vnímání v dějinách lidstva se ve Varšavě uskutečnily v roce 2015 a 2017 dvě interdisciplinární konference z cyklu Antropologiczno-jezykowe wizerunki duszy w perspektywie międzykulturowej, a plánují se další pokračovaní.

(Giuseppe Maiello)

V sekci Dějiny slovanských literatur se zaměřením na problematiku stylu, literárních žánrů a literární tradice vystoupilo pět účastníků. Sekci uváděla ruská slavistka Jelena Nikolajevna Kovtun (Елена Николаевна Ковтун), která nám v př́íspěvku věnovaném postmoderně přiblížila evoluci vyprávění o zvláštních událostech v ruské literatuře z konce 20. a počátku 21. století.

Více o tradici smíchu z období renesance a osvícenství v satirické tvorbě ruských a běloruských spisovatelů počátku 20. století předne- sl Ivan Štejner (Іван Штәйнер) z Běloruska. Polská slavistka Lidia Wiśniewska se zaměřila na nadčasovou postavu Dona Quijota, jejíž atributy můžeme najít $\mathrm{v}$ postavách $\mathrm{z}$ děl současných polských i ruských spisovatelů. Srbský vědec Dragan Chamović (Драган Хамовић) se ve svém příspěvku zabýval poetikou moderní srbské poezie ve srovnání s dalšími jihoslovanskými literaturami. Sekci uzavřela doktorandka z Česka Lenka Paučová s př́spěvkem o motivech živlů, které jsou spjaty s tvorbou ruského klasika F. M. Dostojevského.

Rokování sekce pokračovalo následující den pod vedením americké slavistky Olgy Cook (Ольга Кук). Zazněly celkově čtyři prríspěvky mapující problematiku ruské, chorvatské a srbské literatury. Olga Cook ve svém př́íspěvku představila koncepci literární paměti na základě románu Jevgenije Ginzburg Strmá cesta. Problematice prostoru Moskvy ve vybraných povídkách A. P. Čechova věnovala pozornost Jana Pavlova (Яна Павлова) zе Švýcarska. Česká slavistka Jana Kostincová na příkladu tvorby současných ruských básníků přiblížila možnosti psaní poezie, které s sebou přináší dnešní digitální technika. Další z představitelek americké slavistiky Sibelan Forrester prezentovala překlady tvorby chorvatských a srbských spisovatelek do anglického jazyka.

Diskuze účastníků se nesla ve znamení hledání společných míst a souvislostí mezi slovanskými literaturami - co je však nejdůležitější - přispěla k navázaní kontaktů a dialogu mezi slavisty působícími v Evropě a v Americe.

(Lenka Paučová)

\section{PhDr. et PaedDr. Alexej Mikulášek}

Stredoeurópske areálové štúdiá

Fakulta stredoeurópskych štúdií, Univerzita Konštantína Filozofa

Dražovská 4, 94974 Nitra, Slovensko

alexej.mikulasek@seznam.cz 
Alexej Mikulášek (Praha) - Giuseppe Maiello (Praha) - Lenka Paučová (Brno)

Několik postřehů ze XVI. mezinárodního kongresu slavistů v Bělehradě

doc. dott. Giuseppe Maiello, Ph.D.

Katedra marketingové komunikace

Fakulta ekonomických studií, Vysoká škola finanční a správní v Praze

Estonská 500, 10100 Praha 10, Česká republika

27773@mail.vsfs.cz

\section{PaedDr. Lenka Paučová}

Ústav slavistiky

Filozofická fakulta, Masarykova univerzita

Arna Nováka 1, 60200 Brno, Česká republika

lenka.paucova@mail.muni.cz

Toto dílo Ize užít v souladu s licenčními podmínkami Creative Commons BY-SA 4.0 International (https://creativecommons.org/licenses/by-sa/4.0/legalcode). Uvedené se nevztahuje na díla či prvky (např. obrazovou či fotografickou dokumentaci), které jsou v díle užity na základě smluvní licence nebo výjimky či omezení přislušných práv. 